\title{
Legal Form of Relief Is Free Of Charge by the Person or Group of Advocate for the Poor (Study at Jurisdiction in Ex Residency of Cirebon)
}

\author{
Tofan Alamsyah $^{1}$ and Gunarto ${ }^{2}$
}

Abstract. The problems of this study are: 1) forms of legal assistance free of charge given to the person or group of poor people in the Ex Residency of Cirebon, 2) challenges and solutions lawyers to provide legal assistance free of charge at the Ex Residency of Cirebon, 3) forms of legal protection given for free of charge that given to the person or group of poor people in the Ex Residency of Cirebon in the future.

The method used by researchers is legal approach empirically and specification in this study were included descriptive analysis. Even sources and types of data in this study are primary data obtained from interviews with field studies members of the Police of the Police Ciwaringin and Secretary Untag Jaya, And secondary data obtained from the study of literature relating to the theory of justice and progressive law.

Based on the results of research that form of legal aid free of charge is given to a person or a group of poor people in the Ex Residency of Cirebon, have been met by providing a list of advocates in the district police or through the Legal Aid Post (ZIP Bankum) in each court both the General and courts that exist in the jurisdiction of the Ex Residency of Cirebon. Problems were found in providing legal assistance free of charge to the poor, is not all lawyers enrolled in Posbakum and district police to and willing to help to the poor who need legal help; The solution needed is a regulation that requires all lawyers who have permits proceedings to register and willing to help the poor who need legal aid, and the obligation to serve as a form of professional advocate obligation to perform community service.

Keywords: Legal Assistance Free of Charge; Advocate, Poor.

\section{Introduction}

The Preamble of the Constitution of the Republic of Indonesia 1945, states that the State Republic of Indonesia is a constitutional state. State law in which all use of force must always be no legal basis and is within the framework of the limits set by law. State is an organization, from all levels of society who organize themselves rationally, to jointly endeavor, strive to realize the social welfare for all citizens to adhere to the values of human dignity that is based on God. ${ }^{3}$ Indonesia adheres to the rule of law is a dynamic or welfare state, because the state must ensure the social welfare or the welfare of the community. Referring to this principle that, by itself the task of government is so fast. Government must provide protection to the public, one of them in the legal field ${ }^{4}$ The state must guarantee equality of each person before the law and protect human rights.

Forms of equal treatment before the law is that everyone is entitled to a defense of lawyers in accordance with the provisions of the law, so that not only people who are able only to

\footnotetext{
${ }^{1}$ Student of Master of Law, Universitas Islam Sultan Agung Semarang and Indonesian Police Member, email: taufanalam7@gmail.com

${ }^{2}$ Lecturer of Master of Law, Sultan Agung Islamic University (UNISSULA), Semarang

${ }^{3}$ Bahder Johan Nasution, 2011, Negara Hukum dan Hak Asasi Manusia, CV. Mandar Maju, Bandung, p. 76.

${ }^{4}$ SF Marbun dan Moh. Mahfud MD, 2009, Pokok-Pokok Hukum Administrasi Negara, Liberty Yogyakarta, Yogyakarta, p. 52.
} 
obtain a plea of advocate / lawyer but also the poor or those who could not also be the same right to obtain justice (access to justice). Legal assistance free of charge or fee waiver in the jurisdiction of Ex Residency or Region III Cirebon, including Cirebon, Cirebon, Kuningan Residency, Indramayu Residency, and Majalengka, has been running pro bono basis to provide legal aid to the accused / defendant. The term free of charge or fee waiver is a term that applies to the suspect / accused, but for advocates are not entirely free of charge, because there honorarium between 1 (one) to 2 (two) million provided through the local District Court. Poverty in Jurisdiction Ex Residency of Cirebon is a problem that is very complex, which is not confined to the economic problems, but also related to problems in other areas, the policy of the government is needed to help solve problems related to poverty, especially in the field of law and generally in the field others. Likewise also the role of advocate organizations that exist in the jurisdiction of Ex Residency of Cirebon, both Peradi or IMC, participation less than the maximum, because the advocate is the case today, usually only advocates still an apprentice, because maybe the honorarium is quite small, compared to handle clients who provide services.

Legal aid is the right of poor people who can be obtained free of charge (Pro Bono Publico) as the elaboration of equality before the law. This is in accordance with the provisions of Article 34 UUD 1945 where in it is confirmed that the poor are the responsibility of the state. Moreover, the principle of equality before the law (equality before the law) and the right to be defended advocate (access to legal counsel) is a human right that should be guaranteed in order to achieve alleviation of poverty Indonesia, particularly in the field of law $^{5}$, Therefore it is every citizen, including the suspect / defendant, must be given an equal opportunity to exercise the rights that have been determined by law, such as the right to legal aid, to provide information freely and the right to be tried by a fair trial and impartially ${ }^{6}$.

In line with the background of the problems described above, then the problem is formulated: How do legal aid forms for free of charge given to the person or group of poor people in the Ex Residency of Cirebon?How constraints and advocate solutions to provide legal assistance for free of charge at the Ex Residency of Cirebon?What is the nature of legal protection given for free of charge that given to the person or group of poor people in the Ex Residency of Cirebon in the future?

\section{Research methods}

In this study, the method used is a sociological juridical approach. Juridical sociological (socio-legal approach) intended to study and examine the reciprocal relationship in real terms associated with social variables other. To obtain the data necessary to compile this legal writing, research specifications were used in this research is descriptive analysis, the research aimed to obtain a clear and systematic as to the circumstances or the facts of the problems studied and studied as something intact. ${ }^{7}$

\footnotetext{
${ }^{5}$ Frans Hendra Winarta, 2011, Bantuan Hukum di Indonesia; Hak untuk Didampingi Penasihat Hukum Bagi Semua Warga Negara, PT Elex Media Komputindo Kompas Gramedia, Jakarta, p. vii.

6 Heri Tahir, 2010, Proses Hukum yang Adil dalam Sistem Peradilan Pidana di Indonesia, LaksBang, Yogyakarta, p. 49.

${ }^{7}$ Mukti Fajar ND., dkk, 2010, Dualisme Penelitian Hukum Normatif dan Empiris, Pustaka Pelajar, Yogyakarta, p. 192.
} 


\section{Results And Discussion}

\subsection{Forms of Legal Assistance Free of charge Provided By Advocate To Poor People In Ex Residency of Cirebon}

The role of an advocate as law enforcement a free and independent is guaranteed by law and regulations to be very important in the process of law enforcement. Through the legal services provided, advocate stints justice, including an attempt to empower communities to realize the fundamental rights before the law. Advocate is one element of the judicial system which is one of the pillars in upholding the rule of law and human rights. Under the Act advocates, one form of legal services advocates are given legal aid (Article 1 paragraph 2 of Law advocate). The provision of legal aid by lawyers constitute legal obligations inherent to every lawyer in the position of an advocate as a noble profession (Officium Nobile). ${ }^{8}$

Legal aid is a fundamental right of every citizen, both for the citizens who are able and are classified as not well. When a capable (the haves) have a legal problem, it may appoint one or more lawyers to defend their interests. Likewise one who are poor, (the have not) may request the defense of one or more public defenders (public defender) on legal aid (legal aid institute) to defend its interests in a lawsuit. not fair when people are able to are defended by an advocate in dealing with legal issues, while the poor do not get a defense because it is not prepared to pay services (fee) lawyer ${ }^{9}$,

The provision of legal assistance in criminal, based on interviews with Asep $\mathrm{H}$, members of the Police Police Ciwaringin, given to the suspect since at the level of police investigation, the legal aid granted to suspects liable to a penalty of five years. In order to facilitate the suspect to legal assistance and facilitate advocates to provide legal assistance to the suspect, any suspect who committed the crime with a penalty of over five years, by the concerned police station handed over to the Police in the jurisdiction of the police station is located. Thus the advocates do not have to accompany suspects in police that distance or location may be difficult to reach and the costs for transportation. ${ }^{10}$

The interview with the Secretary of the Legal Aid Untag Jaya ${ }^{11}$ states that although LBH Untag Jaya is LBH within the scope of Higher Education under the auspices of the Faculty of Law Untag Cirebon, the memorandum has many legal experts and lawyers who have a doctoral degree, but in giving aid-free basis is relatively still very rare who are willing, as advocates concerned has a regular client who must be helped, while aid-free basis is simply a form of devotion which has no legal sanctions if it does not do.

\subsection{Obstacles and Solutions to Provide Advocates for Legal Aid Free of Charge Ex Residency of Cirebon Jurisdiction}

Lack of advocates who registered as lawyers who are willing to provide legal assistance free

\footnotetext{
${ }^{8}$ Frans Hendra Winarta, 2011, Bantuan Hukum di Indonesia; Hak untuk Didampingi Penasihat Hukum Bagi Semua Warga Negara, PT Elex Media Komputindo Kompas Gramedia, Jakarta, p. 104.

9 Frans Hendra Winata, 2009, Pro Bono Publico Hak Konstitusional Fakir Miskin Untuk Memperoleh Bantuan Hukum, Jakarta: Penerbit Pt Gramedia Pustaka Utama, Jakarta, p. 1.

${ }^{10}$ Results Interview with H. Asep, members of the Police of the Police Ciwaringin, on December 10, 2019, 13:00 pm

${ }^{11}$ Results Interview with Br Lukmannulhakim, Secretary Untag Jaya, on 11 October 2019, the Office Untag LBH Jakarta Jl. Perjuangan Cirebon City.
} 
of charge illustrates that the duty lawyer to be able to provide rock law-free basis to people who could not be implemented by all advocates who gets a license to practice, nonfulfillment of the obligation to provide legal assistance free basis by advocates in the absence of adequate regulation provides that ignores the threat to community advocates who need legal help. ${ }^{12}$

Based on the foregoing, it can be concluded that the difficulties in providing legal aid by advocates for people who are not able or disadvantaged people is plagued by the following:

- The absence of lawyers specialize in handling a case either free of charge or to services, both litigation and non-litigation

- Not all lawyers to register in the Legal Aid Post (ZIP Bankum) in the territory of the former law Residency of Cirebon.

- There is no regulation that can threaten advocates have enrolled to provide legal aid to the Legal Aid Post underprivileged or poor.

In line with the obstacles or problems advocate in providing assistance free of charge to the poor people, the author tries to give a solution as follows:

- With will shift Advocate education to universities that level with the Strata 2 (masters) and within the framework of improving the quality of Advocates in Indonesia, should be considered to issue regulations Master Degree Advocate divided into certain specialties, such as the concentration of the science of criminal law, the science of civil law, jurisprudence State administration, and other concentration needed in the community within the framework of law enforcement.

- Advocates who have been providing legal assistance free of charge must be given a Certificate of Legal Aid Has Done free of charge to the poor by law Posbakum concerned.

- Within the framework of justice for all parties, especially for the poor or disadvantaged, the Act related to the obligation of lawyers providing legal assistance for the poor should be reconstructed or revised again.

\subsection{Forms Of Legal Protection Provided Free Of Charge That Given To Poor People of Ex Residency of Cirebon In Future}

The principal tasks of an advocate in proceedings is filed facts and considerations relevant to the clients who defended in a case so as to allow the judge gives the fairest decision. Judging from the very important role the advocate profession is an honorable profession on its personality. As for the legal basis of professional advocate the need for the Islamic perspective derived from the Qur'an, the Hadith and consensus of scholars.

In a hadith mentioned: And God will help His servant for a servant to help his brother. (HR. al-Hâkim) ${ }^{13}$

Forms of legal protection given for free of charge is given to a person or a group of poor people in the Ex Residency of Cirebon in particular and in general in the Republic of Indonesia in the future, in order to satisfy the justice and legal politics of the enactment of Legal Assistance, already ought that legal aid is not simply give or provide a lawyer who is willing to assist the poor, but also should be tailored to the capabilities and specialization of

\footnotetext{
12 Results Interview with H. Asep, members of the Police of the Police Ciwaringin, on December 10, 2019, 13:00 pm

${ }^{13}$ Abû 'Abd Allâh Muhammad ibn Muhammad al-Hâkim, 1410 H, Al-Mu - tadarak 'alâ Shahîhayn, Dâr alKutub al-'Ilmiyyah, Ed.I, Section VI, Bayrût. p. 427
} 
lawyers who will assist and provide legal assistance free of charge, so that the proceedings will help judge court was lit up against the case being examined, for it is within the framework of providing justice to the entire community, then advocate general conduct or proceedings in all cases that exist, but based on a specialist and specificity according to the course which he passes while following the lecture, it is that the competition between advocates are not too tight, to the advocates who are given permission to carry out the practice must determine and specialist exams before being sworn, and specialization should advocate more than one specialization but all must be pursued through the exam and no certificate, but it must be determined which of its maximum certified. Against advocates must be required to perform or undergo community service by providing legal assistance in accordance with his specialty at least once a year and the service as a condition for extending the permit practice, the advocates of this provision will not ignore people who need legal assistance free of But, in addition to overcome the shortage of lawyers to meet demand of poor people who need legal help. ${ }^{14}$ Thus within the framework of legal reform in Indonesia, then the liability lawyers to provide legal assistance to be reconstructed, to make this obligation as a prerequisite an advocate in order to extend the permit practice, so advocate who do not have sociality to the poor and never do or provide legal assistance on the poor, then the practice permit will not be extended.

\section{Closing}

\subsection{Conclusion}

- Forms of legal aid free of charge is given to a person or a group of poor people in the Ex Residency of Cirebon, have been met by providing a list of advocates in the district police or through the Legal Aid Post (ZIP Bankum) in each court both the General and courts that exist in the jurisdiction of the Ex Residency of Cirebon, however, not all lawyers or lawyers who have a license to practice practice enroll and present herself to be willing to be an advocate who is willing to provide legal assistance free of charge.

- Problems were found in providing legal assistance free of charge to the poor, is not all lawyers enrolled in Posbakum and district police to and willing to help to the poor who need legal aid, a solution that is needed is a regulation requiring all advocate has a permit proceedings to register and willing to help the poor who need legal aid, and the obligation to serve as a form of professional advocate obligation to perform community service.

- Forms of legal protection given for free of charge given to the person or group of poor people in the Ex Residency of Cirebon or in another jurisdiction in Indonesia in the future need to look for a solution, either to require all lawyers to provide legal aid free of charge, or their legal specialization of lawyers who got a license to practice proceedings.

\subsection{Suggestion}

- Relative Legal Aid Post (Posbakum) still requires a lot of Advocates to provide legal aid services to the poor or can not afford, should any advocates who want to extend the

\footnotetext{
${ }^{14}$ Results Interview with H. Asep, members of the Police of the Police Ciwaringin, on December 10, 2019, 13:00 pm
} 
permit practice burdened by the obligation to submit the Certificate has conducted legal assistance to the poor as a form of devotion to the profession Advocate to the public.

- In line with the Advocate Education or profession of Advocate in the future should be of graduate Strata 2 (S2) or Master of Law, should be considered to impose specialization advocate in the future, in accordance with the concentration of college, if the concentration of the Criminal Law, Civil Law or the other, thus Advocate in the future will be divided into certain specializasion.

- In connection with the above two suggestions, and suggestions mentioned above are not in the regulation of Law Advocates and Legal Assistance Act, the legislation in question should be revised or reconstructed.

\section{References}

[1] Abû 'Abd Allâh Muhammad ibn Muhammad al-Hâkim, 1410 H, Al-Mu - tadarak 'alâ Shahîhayn, Dâr al-Kutub al-'Ilmiyyah, Ed.I, Section VI, Bayrût

[2] Bahder Johan Nasution, 2011, Negara Hukum dan Hak Asasi Manusia, CV. Mandar Maju, Bandung

[3] Frans Hendra Winarta, 2011, Bantuan Hukum di Indonesia; Hak untuk Didampingi Penasihat Hukum Bagi Semua Warga Negara, PT Elex Media Komputindo Kompas Gramedia, Jakarta

[4] Frans Hendra Winarta, Bantuan Hukum Suatu Hak Asasi Manusia Bukan Belas Kasihan, PT. Elex Media Komputindo Kelompok Gramedia, Jakarta

[5] Frans Hendra Winarta, 2009, Pro Bono Publico Hak Konstitusional Fakir Miskin Untuk Memperoleh Bantuan Hukum, Jakarta: Penerbit Pt Gramedia Pustaka Utama, Jakarta

[6] Heri Tahir, 2010, Proses Hukum yang Adil dalam Sistem Peradilan Pidana di Indonesia, LaksBang, Yogyakarta

[7] Mukti Fajar ND., dkk, 2010, Dualisme Penelitian Hukum Normatif dan Empiris, Pustaka Pelajar, Yogyakarta

[8] SF Marbun dan Moh. Mahfud MD, 2009, Pokok-Pokok Hukum Administrasi Negara, Liberty Yogyakarta, Yogyakarta 